\title{
An Examination of the Switching Behavior of the Customers in Cellular Industry of Pakistan
}

\author{
Muhammad Rizwan \\ Lecturer, Department of Management Sciences, \\ The Islamia University of Bahawalpur, Pakistan \\ Email: rizwan.arshad@iub.edu.pk
}

Farzana Sadaf

MS Scholar, Department of Business Administration

NCBA\&E, Bahawalpur, Pakistan

Sabiha Hafeez

MS Scholar, Department of Business Administration

NCBA\&E, Bahawalpur, Pakistan

Hira Naz

MS Scholar, Department of Business Administration

NCBA\&E, Bahawalpur, Pakistan

Accepted: September 13, $2013 \quad$ DOI: 10.5296/jpag.v3i3.6225

\begin{abstract}
There is strong competition and rapid change in technology cell phone industry. Cellular industry has to build up customer-oriented strategies in order to compete effectively in the competitive environment. The longer a brand can retain a customer, the greater revenue and cost savings from that customer. Pakistani customer have greater choices between multiple cell phone brands. This study aims to identify and analyses the factors that influence cell phone users and adoption of high technology cell phone brands.

Facts and figures for this research were collected by using a convenience Sample of 160 cell phone users in Bahawalpur City, Punjab Province, Pakistan. The decision to switch the cell phone brand or to be loyal with current cellular brand is hypothesized to be a function of
\end{abstract}


customer satisfaction that is ultimately has strong relation with, service quality and brand commitment, switching cost also has great impact on the both dimension of customer either to be loyal with brand or to switch. Here switching cost also play very important role to keep customer loyal with brand.

The research findings reveal that service quality brand commitment impact on customer's satisfaction level. As this level increase, it makes a customer loyal and in decrease in satisfaction level leads to switching behavior of customer. Switching cost also play a key role to keep loyal a customer even if he/she want to change the cell phone brand. The findings also reveal that the young and high-income groups are more likely to switch towards high technology cell phone brand.

Keywords: customer switching behavior in cellular industry, customer loyalty, Brand commitment

\section{Introduction}

There is critical issue for cellular industry in present competitive environment to build long term relationship with their customer. Deregulation and materialization of new technology in cellular industry have greater influence on behavior of customer. To find out the reason of customer switching behavior is very important because result of this behavior is greater loss in future. Garland, (2002) demonstrate in his research customer switching stand for customer relinquish one source/supplier for another.

Previous researches find out many factors are relevant to switching behavior and cause inconvenience for customer like pricing, failure in providing core services, failure in providing best quality, competition and low level of awareness or less switching cost. Many investigate combination of numerous features so as to become reason of customer switching.

To enhance customer satisfaction various strategies are available ,manage customer retention programme or create switching barriers to prevent customer switching. Different brands in cellular industry can maintain high level of customer satisfaction developing diverse relational benefits that give to regular customers. Although numerous researches reveal, customer satisfaction definitely influence loyalty of customer but is not constantly valuable circumstance if this become unsuccessful to generate the expected results. So, research also propose some other factors that is necessary to analyze.

Cell phone companies should manage to accomplish customers requirements and prevent their switching for other brands, first they have to understand customer needs, and their expectations solve these issues by focusing on relationship marketing and create great interest of customers in their product by improving quality to find out ways to maximize shopping benefits and maximizing shopping cost.

Oliver,1997 stated that usually customer satisfaction means customer response of contentment and customer's opinion to the contented condition. It enhance 
loyalty of customer and prevents customer to be disloyal, It decrease customer price compassion, reduce cost of failed marketing and new customer entering, reduce OC(operating cost),improve Ad (advertisement) effectiveness and enhance business reputation.

Brand commitment is faithfulness of an person to his/her brand choice. Commitment is an important factor because it influence customer to be switching. Jones and sassar 1995 p-94 stated that Customer loyalty is a feeling of attachment to or affection for a company product or services so, customer loyalty is combination of customer favorable attitude and behavior of repurchase.

Garland,2002 defined customer switching means customer relinquish of one service provider for another. Basu \& Dick 1994 disclose that cost that incurred when switching, is called switching cost, it include psychological cost, time, and money . Gilly \& Gronhang (1991) note that if switching costs are too high dissatisfied customer might stay with their present supplier. We define switching cost in three terms that is adaptation cost move in cost and loss cost.We define adaptation cost as cost of perceived adaptation like searching cost, searching for better option for new source for a new product. Loss cost referred to cancelling the use of product and directly impact social status of a person and move in cost include shifting cost or economic cost involved switching to a new supplier. Overall purpose of this research is to identify and examine the aspects that influence customer switching behavior in cellular industry.

\section{Literature Review:}

\subsection{Customer satisfaction:}

Oliver in 1997 state this Customer satisfaction is usually about condition of individual fulfillment and his/her judgment of fulfilled condition about product. Fornell (1992) said that Customer attitude is influenced after the usage of products or services. A study by Crosby et al (1990) explore this fact, satisfaction is the tools for assessing experience of customer interacting with an organization up to the present time, and it can used to predict customer future behavior on the basis of past experience about that product.

Zeithaml \& Bitner (2000) also express customer satisfaction as it is a wide feeling and influenced by many factors like quality, price contextual and personal factors and satisfaction is essential forecaster of customer loyalty. According to past researches by Dick \& Basu, 1994, deRuyter \& Wetzels, 2000, Deng, and Lu, Wei, \& Zhang,2009, satisfaction definitely influence customer loyalty and build attachment feelings.

Gerpott,Rams,\&Schindler,2001 stated in their research, though it is quite right to say that satisfied customers are more loyal but it does not mean that loyal customers are always satisfied from a product. Switching behavior of a customer is expected to depend on dissatisfaction consequential from previous use of brand ( Mazursky and LaBarbera ;1983).In 2003 Burnham et al, acknowledged that satisfied customers are more loyal with their source and they become determined to stay with the brand. 
Mazursky and LaBarbera (1983) identifies that the switching behavior of the customers towards brands is expected to depend upon the intensity of dissatisfaction resulting as of former use of the brand. While according to Droge and Chiou, 2006, satisfaction or dissatisfaction of the customers alone is not sufficient to identify that customer will remain loyal or become disloyal with the brand that they experienced in the past.Another perspective disclose by Jones et al, 2000 as the level of satisfaction increase, it diminish chances of customer switching, accordingly, it leads to higher level of customer loyalty. Coulter et al. (2003) stated that there is less probability of switching of satisfied customer toward any other brand because these feelings make customer bonding strong with brand.

\subsection{Service quality:}

Berry, Parasuraman, \& Zeithaml (1988) indicate service quality resulted in the understanding of the insubstantial, diverse, and indivisible nature of the anything, also they considered it as difference customer's expectation about the product and its apparent quality.

Gronroos,2000 \& Bitner and Hubbert,1994 argued that communication between customer and company provide chance for customers to evaluate the quality and it could generally conceptualized as comparative inadequacy or dominance of brand with others. Past researches also confirmed that service quality is multi directional scale and it possesses the different aspects and ethnicity of industry. (Brady \& Cronin, 2001;Alexandris et al, 2002; Dagger et al, 2007; Clemes et al, 2007b).

Zeithaml et al.1996 and Aydin and Ozer, 2005 identifies that low level of customer loyalty and adverse behavioral intention can be caused by meager quality of service. Loannou and Mavri (2008) found that the quality of the products and services offer by the providers had a positive influence of decreasing switching behavior of the customers.

H1: Service quality is positively associated with customer satisfaction.

\subsection{Brand commitment:}

Lastovicka and Gardner, 1978, p.90, Kiesler, 1968, p 448 defined brand commitment as the pledging or binding of an individual for his/her preferred brand and said; to prevent customers switching primarily the brand commitment is very important. A general concept exist that it also play a role of exit barrier and brand commitment is a necessary condition the occurrence of true brand loyalty because it the raises level of customer satisfaction.According to Hamilton et al. (2009) consumers are attracted by the introduction of a new brand or a new product and it shows that their loyalty to existing products decreased by introduction of new brand.

In contrast, Raju et al. (2009) propose that there are two directions of brand commitment, first one is confirmatory processing and second is disconfirmatory processing.Confirmatory processing takes place when compare the similarities between preferred brand and the competitor brand while on the other side disconfirmatory processing focused on the differentiation between customer preferred brand and the competitor brand. In confirmatory processing customer's brand commitment is low, while on the other hand in disconfirmatory 
it is on high level.

Wang \& Cui (2010) demonstrated that during online shopping customers choose products as stock keeping unit level instead of level of brand commitment or loyalty, which affects the consumer decision process. Coulter et al. (2003) stated that there are less chances of switching of satisfied customers with current brand. Mazursky \&LaBarbera (1983) also supported the concept that satisfaction play pivotal role to prevent switching behavior of consumers that is strongly attached with brand commitment in cell phone industry.

H2: Brand commitment is positively associated with customer satisfaction.

\subsection{Customer loyalty:}

Oliver, 1999, p.34 defined loyalty as a state of emotion "a deeply held commitment to re-buy or re-patronize a preferred product/service consistently in the future". Sasser and Jones (1995) acknowledged that customer loyalty is a emotion of affection to or liking for a company's product, for its name or fame. They also add there are two belonging of this term, and $!^{\text {st }}$ is the unstable relation (short term loyalty) and $2^{\text {nd }}$ is stable relation(long term loyalty). These two belongings are defined as the customers with short-term loyalty detect the defect and switch to the alternatives for betterment, on the other hand customers having long-term loyalty restrict their boundaries and avoid switching to other alternatives.

Fornell, 1992 \& Reichheld, 1996 stated there two terminologies customer satisfaction and customer loyalty are closely related to each other. The term Customer satisfaction functions as forerunner of customer loyalty. It works as a guard which retains the customer attention, it prevents customer churn and consolidates retention, the re-buy constituting an important cause of customer loyalty. There is a positive relationship between customer satisfaction and customer loyalty, although there is no linear relation (Fornell, 1992; Soderlund, 1998). Customer loyalty is highly influenced by the risk of switching barriers when a customer switches towards an attractive alternative.

In response of dissatisfactory condition, Hirschman (1970) said customer loyalty is influenced by the behavior of dissatisfaction. He argued that a customer who is not satisfied, this may has comprised primarily two reasons: any bad experience, very harsh response in discontinuing, due to this they exit, and other cause is problem in communication the resultant is concluded as the higher the dissatisfaction response is, the lower the customer loyalty.

H3: Customer satisfaction is positively associated with customer loyalty.

\subsection{Switching cost:}

Switching cost is a valuable phrase that describes the variety of financial and non financial costs occurred while changing suppliers (Matthews and Murray, 2007). In 1980 Porter characterized switching costs as "one-time costs facing the buyer of switching from one supplier's product for another's"; notion of switching costs can be as the supposed as the degree of the extra costs required to come to an end the existing relationship and secure an alternative. 
However, Keaveney, 1995 explain the switching cost may be comprised of psychological and emotional costs. The cost arise from switching for another provider can be measured by the switching cost (Cunningham and Lee, 2001). According to Chang and Chen (2007) the loyalty is positively affected by the switching barriers of customer. Cost that a customer bear during switching process, including psychological, money and cost time all these factors are included in switching cost ( Dick \&Basu, 1994).

One of the $1^{\text {st }}$ generalized models to investigate several factors that influenced customers to switch service a provider was developed by Keaveney (1995). Fornell (1992) explains that high switching costs can prevent switching by making it costly for customers to change service providers by realizing the values they will lose if they switch towards the alternative.Colgate and Lang (2001) investigated switching barriers in the New Zealand and found that if the switching cost is high it will restrict your customer to switch even if he has completely diverted its mind to consider the alternative to switching provider.

Over a period of time there is a relation of trust have been built between the customer and the service provider it will become emotionally attach and these feelings become exit barrier(cost), even in the condition when they are not satisfied with the performance of the product that is currently in their usage. Hunt and Morgan, 1994 explained it might b possible customer stay with their current product just because of a thought, if there is defection in the current product, it might $\mathrm{b}$ possible after bearing switching cost there could be other problems and defection in new ones.

H4: Switching cost is positively associated with customer loyalty.

\subsection{Customer Switching Behavior:}

A behavior of customer switching is defined as disowning a service provider for the sake of betterment. Customer switching means customers forsake one service provider for another (Garland, 2002). The cellular industry is change because of rapid change of technology and the customer behavior.In a study Making Every Interaction Count Game Fly Aligns its Customer Experience, 2007 it is declared due to new technology and awareness, customers are sharp and knowledgeable in buying decisions, about products and they are intelligent to examine the value and fame of company and its products by communicating with others or through internet. They can quickly switch to others due to new technology and other reason, might be possible they are unhappy from the quality of current product.

In 1995, first generalized model was proposed by Keaveney to examine a number of factors that have impact on customers to switching behavior. Hocutt, 1998, Palmer \& Bejou 1998 discover that It might be logical to suppose that customers switching behavior arise from a single unpleasant reason, or it is consequential of various problems happened over the time period.

Cunningham and Gerrard, 2004, Murray and Matthews and, 2007, Clemes et al., 2007a, Hedge and Colgate 2001 all these researchers have considered a combination of numerous factors that cause customers switching, so that they should develop strategies that could reduce the negative effects and enhance relation with customers. 


\section{Macrothink}

H5: Customer satisfaction is negatively associated with customer switching behavior.

H6: Switching cost is negatively associated with customer switching behavior.

\section{3-Conceptual Model:}

\section{Hypothetical Model For Research}

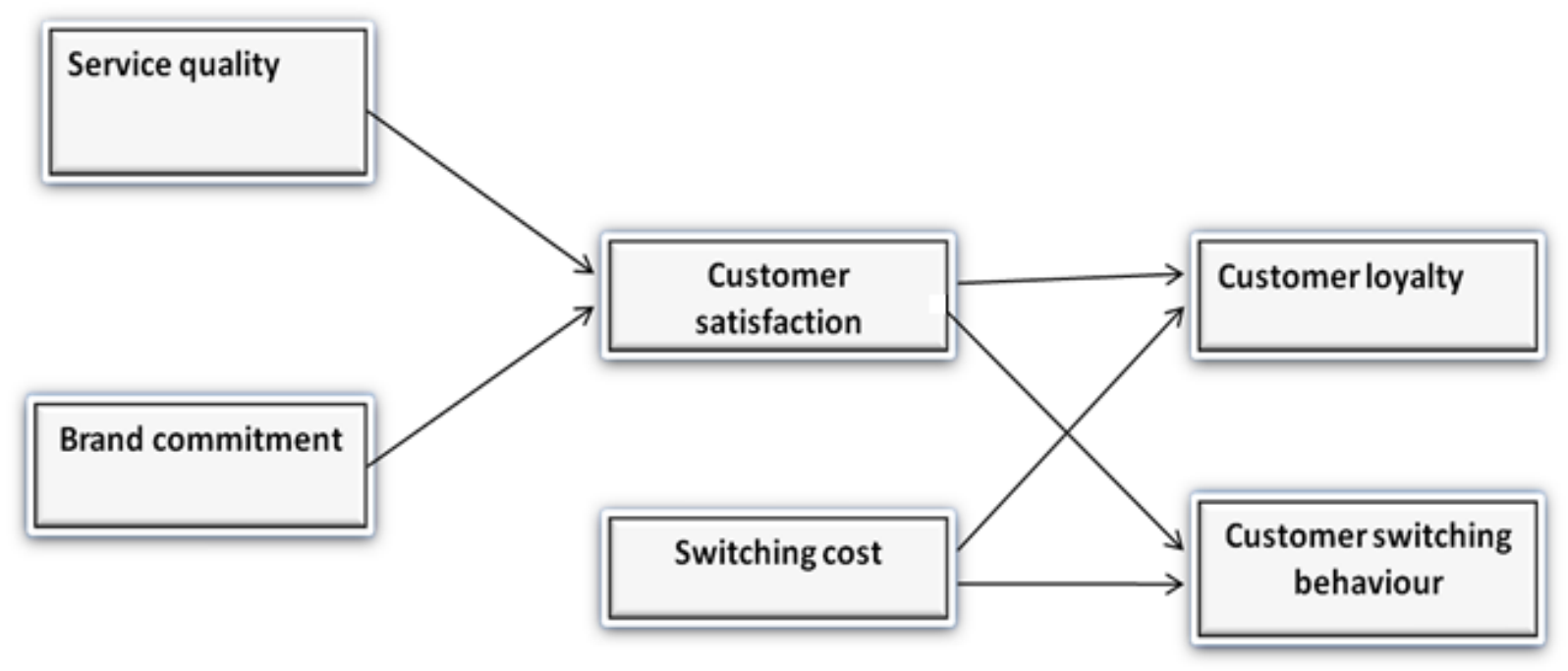

\section{Methodology:}

The methodology involves the descriptive method in this research. Descriptive study is defined as to elaborate something, any phenomena, or to explain a specific situation. By another researcher the descriptive research is defined as the current condition of a scenario instead of interpreting and making judgments (Creswell, 1994). Verification of the developed hypotheses that reflect for the current situation is the purpose of this method. The research provides information current the current scenario and focus on past or present for example quality of life in a community or customer attitudes towards any marketing activity (Kumar, 2005).

\subsection{Sample}

To conduct the research the sample is selected of about 200 respondents they will participate in the self administered questionnaire. The population for the current research is cell phone users in Pakistan. A non-probability sampling technique used in the current study and that is convenience sampling. The relevant data is collected and obtained by using this convenience sampling technique from the sample or the unit of the study that are conveniently available (Zikmund, 1997). Usually for collecting a large number of completed surveys speedily and with economy convenience sample technique are used (Lym et al., 2010).

To obtain the appropriate result from this study it has ensured that the respondents must have 
two major characteristics to take part in this self-administered survey. First, cell phone is in use of the respondent with the enough knowledge about the other brands. Second, is the objective of the study their loyalty or switching behavior for particular cell phone brand on the basis of their experience, it definitely influences the attitude and behavior of the respondent.

We select these respondents from one city of Pakistan. Two main groups will target to gather the sample information: university students and working professionals. The selection of respondents (students and working professionals) based on the prior results of the studies on switching behavior in Pakistan.

\subsection{Instrument and Measures}

In this research the survey instrument of the current study address two major purposes: First is the adoption of high technology cell phone brands and to analyze the relationship of different variables in the adoption. Second, to collect information about the different characteristics of the respondents that can be used to understand the variations in different categories. The survey instrument contains two sections. Section 1 includes different personal and demographic variables. This section will obtain the respondent's information about gender, age, income, education, status, frequency of internet use and possible product to be purchased in the future.

Section 2 includes the latent variables that are important in the current study. These variables include service quality, brand commitment, customer satisfaction, and customer loyalty, customer switching behavior and switching cost towards online shopping. This section of the study is developed based on the past literature and already used questionnaires (Table 1).

The scales of the study were adopted from the previous literature and published studies. The first three variables of the study were service quality, brand commitment and customer satisfaction. Each variable have different items and these scales were taken from Chang and Chen (2007). The next variable is customer loyalty having eight items was taken from Yoo et al, (2000). The last variable is switching behavior have six items to evaluate reasons for this behavior and this scale was taken from Chang and Chen (2007). ............

\subsection{Procedure:}

The questionnaire was distributed among 200 respondents Bahawalpur. These respondents are selected based on the criteria above mentioned. Before giving the questionnaire, the purpose of study and questions were explained to the respondents so they can easily fill the questionnaire with relevant responses. A total of 160 questionnaires were selected and rest of the questionnaires was not included in the further analysis due to incomplete or invalid responses. After collecting the completed questionnaires, these questionnaires were coded and entered into SPSS sheet for further analysis. 


\section{Macrothink}

Table no.1:Scales used for research:

\begin{tabular}{|c|c|c|c|}
\hline No. & Variable & Item & Reference \\
\hline 1 & $\begin{array}{l}\text { Service } \\
\text { Quality }\end{array}$ & $\begin{array}{l}\text { 1. This cell phone brand is successful to complete its } \\
\text { life(Warranty) } \\
\text { 2. This cell phone is modern equipment } \\
\text { 3. This cell phone has many visually appealing facilities } \\
\text { 4. This cell phone brand having customer best interest at heart }\end{array}$ & $\begin{array}{l}\text { Yoo et al, } \\
(2000)\end{array}$ \\
\hline 2 & $\begin{array}{l}\text { Brand } \\
\text { commitment }\end{array}$ & $\begin{array}{l}\text { 1. I usually tell my friends that this is a great cell phone brand to } \\
\text { purchase. } \\
\text { 2. Iam proud to tell others that I am user of this cell phone brand } \\
\text { 3. For me this is the best of all possible cell phone brand to have } \\
\text { 4. I am extremely glad that I choose to purchase this touch screen } \\
\text { cell over others I was considering } \\
\text { 5. I really care about this cell phone brand } \\
\text { 6. I would accept almost any type cost in order to keep this new } \\
\text { model of this cell phone brand } \\
\text { 7. I am willing to put in a great deal of effort beyond that normally } \\
\text { expected in order to help this cell phone brand to be } \\
\text { successfully }\end{array}$ & $\begin{array}{l}\text { Chang and } \\
\text { Chen }(2007)\end{array}$ \\
\hline 3 & $\begin{array}{l}\text { Customer } \\
\text { loyalty }\end{array}$ & $\begin{array}{l}\text { 1. This cell phone brand would be my first choice } \\
\text { 2. I consider myself to be loyal to this brand } \\
\text { 3. I will not buy other brands if the same product is available at } \\
\text { the store } \\
\text { 4. I recommend this cell phone brand to someone who seeks my } \\
\text { advice } \\
\text { 5. I get good value for my money } \\
\text { 6. I say positive things about this brand to other people } \\
\text { 7. Iam willing to pay premium price over competing products to }\end{array}$ & $\begin{array}{l}\text { Chang and } \\
\text { Chen (2007) }\end{array}$ \\
\hline
\end{tabular}




\section{Macrothink}

\begin{tabular}{|c|c|c|c|}
\hline & & $\begin{array}{l}\text { be able to purchase this brand again } \\
\text { 8. I consider this brand my first choice in the next few years }\end{array}$ & \\
\hline 4 & $\begin{array}{l}\text { Customer } \\
\text { Satisfaction }\end{array}$ & $\begin{array}{l}\text { 1. Overall I am satisfied with specific experience with this cell } \\
\text { phone brand } \\
\text { 2. I am satisfied with my decision to purchase from this brand }\end{array}$ & $\begin{array}{l}\text { Ragunathan } \\
\text { and } \\
\text { Irwin(2001) }\end{array}$ \\
\hline 5 & $\begin{array}{l}\text { Switching } \\
\text { Behavior }\end{array}$ & $\begin{array}{l}\text { 1. I attend to switch my current cell phone } \\
\text { 2. Next time I shall need cell phone of other brand } \\
\text { 3. I would not continue to have cell phone from my current brand }\end{array}$ & $\begin{array}{l}\text { Yoo et al., } \\
2000\end{array}$ \\
\hline 6 & $\begin{array}{l}\text { Switching } \\
\text { cost }\end{array}$ & $\begin{array}{l}\text { 1. Switching to new cell phone causes monetary cost } \\
\text { 2. If I switched to a new cell phone brand, the services offered by } \\
\text { the new cell phone brand might not work as well as expected } \\
\text { 3. Even if I have enough information, comparing the cell phone } \\
\text { brand with each other takes a lot of energy, time and effort } \\
\text { 4. If I switched to new cell phone brand,I could not use some } \\
\text { services (MMS.GPRS, WAP,etc.) until I learned to used them } \\
\text { 5. I cannot be sure that the new cell phone brand can provide } \\
\text { better service quality than the old one } \\
\text { 6. Overall, it would cost me a lot of time and energy to find an } \\
\text { alternative cell phone. }\end{array}$ & $\begin{array}{l}\text { Chang and } \\
\text { Chen (2007) }\end{array}$ \\
\hline
\end{tabular}

\subsection{Reliability Analysis}

Overall Cronbach's alpha of adoption of high technology cell phone brands questionnaire items were more than acceptable because recommended value 0.50 by Nunnally (1970) and 0.60 by Moss et al. (1998). This shows that all the 30 items were reliable and valid to measure the opinions of consumers towards high technology cell phones. 


\section{Macrothink

Table no. 2: Reliability of Measurements Instrument

\begin{tabular}{|l|l|l|}
\hline Scales & Item & Cronbach Alpha \\
\hline Service Quality & 4 & .670 \\
Brand Commitment & 7 & .689 \\
Customer Satisfaction & 2 & .652 \\
Customer Loyalty & 8 & .827 \\
Switching Cost & 6 & .664 \\
Switching Behavior & 3 & .667 \\
\hline
\end{tabular}

\section{Results and Analysis}

\subsection{Profile of the Respondents}

Personal and demographic information of respondents such as gender, age, income, education level, status, rate of changing cell phone and the cell phone brand they currently using are presented in the following table.

Table 3: Profile of the Respondents

\begin{tabular}{|l|l|l|l|}
\hline Variable & category & Frequency & Percentage \\
\hline Gender & Male & 74 & 46.3 \\
Female & 86 & 53.8 \\
\hline Age & $15-20$ Years & 35 & 21.9 \\
$20-25$ Years & 94 & 58.8 \\
$25-30$ Years & 19 & 11.9 \\
Income & $30-35$ Years & 5 & 3.1 \\
& $35-40$ years & 7 & 4.4 \\
& Below 15000 & 47 & 29.4 \\
$15000-25000$ & 60 & 37.5 \\
& $25000-35000$ & 17 & 10.6 \\
$35000-45000$ & $45000-55000$ & 9 & 5.6 \\
\hline
\end{tabular}




\begin{tabular}{|c|c|c|c|}
\hline & Above 55000 & 13 & 8.1 \\
\hline Education & $\begin{array}{l}\text { Matriculation } \\
\text { Inter } \\
\text { Bachelor } \\
\text { Master } \\
\text { MS / MPhil } \\
\text { PHD }\end{array}$ & $\begin{array}{l}7 \\
12 \\
26 \\
80 \\
31 \\
4\end{array}$ & $\begin{array}{l}4.4 \\
7.5 \\
16.3 \\
50.0 \\
19.4 \\
2.5\end{array}$ \\
\hline Status & $\begin{array}{l}\text { Student } \\
\text { Employed } \\
\text { Businessman } \\
\text { Unemployed } \\
\text { Housewife }\end{array}$ & $\begin{array}{l}109 \\
33 \\
13 \\
4 \\
1\end{array}$ & $\begin{array}{l}68.1 \\
20.6 \\
8.1 \\
2.5 \\
0.6\end{array}$ \\
\hline $\begin{array}{l}\text { Cell phone brand } \\
\text { currently using }\end{array}$ & $\begin{array}{l}\text { Nokia } \\
\text { Q Mobile } \\
\text { Samsung } \\
\text { G Five } \\
\text { Apple I phone } \\
\text { Huawai } \\
\text { HTC } \\
\text { XA } \\
\text { Lumina }\end{array}$ & $\begin{array}{l}98 \\
15 \\
12 \\
10 \\
8 \\
5 \\
5 \\
3 \\
4\end{array}$ & $\begin{array}{l}61.3 \\
9.4 \\
7.5 \\
6.3 \\
5.0 \\
3.1 \\
3.1 \\
1.9 \\
2.5\end{array}$ \\
\hline $\begin{array}{l}\begin{array}{l}\text { Frequency } \\
\text { for } \\
\text { changing } \\
\text { phone }\end{array} \\
\text { cell }\end{array}$ & $\begin{array}{l}\text { Oftenly } \\
\text { As new model } \\
\text { launched } \\
\text { After } 6 \text { month } \\
\text { After } 1 \text { year } \\
\text { Rarely }\end{array}$ & $\begin{array}{l}23 \\
13 \\
\\
19 \\
30 \\
75\end{array}$ & $\begin{array}{l}14.4 \\
8.1 \\
11.9 \\
18.8 \\
46.9\end{array}$ \\
\hline
\end{tabular}




\subsection{Hypothesis Testing:}

\subsubsection{Service quality, Brand commitment and Customer satisfaction:}

According to the results of the study, the both variables service quality and brand commitment have a significant positive relationship with customer satisfaction. Specially, service quality has a significant positive relationship with $(\beta=0.214)$ and $(p<0.010)$ It means that service quality contribute more than $21 \%$ to customer satisfaction.

The regression results of brand commitment with customer satisfaction is also significant with $(\beta=.378)$ and $(\mathrm{p}<0.000)$. Regression results declare that brand commitment contribute $37 \%$ to customer satisfaction. Results of the current study validate the $\mathrm{H} 1$ and $\mathrm{H} 2$.

\subsubsection{Customer satisfaction, switching cost and customer loyalty:}

Regression Analysis of the switching behavior study that there is a significant positive relationship of customer loyalty with customer satisfaction with $(\beta=552)$ and $(p<0.000)$. These result shows that customer satisfaction contributes $55 \%$ to customer loyalty.

The regression analysis of the study shows that there is a significant positive relationship between customer loyalty and switching satisfaction with $(\beta=.192)$ and $(p<0.003)$. According to these results, switching cost contributes more than $19 \%$ to customer loyalty. The results of this exploratory research support H4 and H5.

\subsubsection{Switching behavior, customer satisfaction and switching cost}

While considering the significance between switching behavior and customer satisfaction the results of the current study shows insignificant relationship between customer satisfaction and customer switching behavior with $(\beta=-0.072)$ and $(\mathrm{p}>0.375)$.According to the results, there is significant but negative relationship between switching behavior and switching cost with $(\beta=-.201)$ and $(p>0.014)$. Based on these results, we reject H5 conclude that the study did not find significant relationship of customer satisfaction and customer switching behavior.

Table no.3.Regression analysis

\begin{tabular}{|c|c|c|c|c|c|c|}
\hline Hypothesis & Model Variables & Estimate & S.E. & C.R. & $\mathbf{P}$ & Results \\
\hline $\begin{array}{l}\text { H1 } \\
\text { H2 }\end{array}$ & $\begin{array}{l}\text { Cust_sat } \\
\text { serv_qty } \\
\text { Cust_sat } \longleftarrow \\
\text { brnd_comit }\end{array}$ & $\begin{array}{l}.214 \\
.378\end{array}$ & $\begin{array}{l}.106 \\
.106\end{array}$ & $\begin{array}{l}2.618 \\
4.615\end{array}$ & $\begin{array}{l}.010 \\
.000\end{array}$ & supported \\
\hline $\begin{array}{l}\text { H3 } \\
\text { H4 }\end{array}$ & $\begin{array}{l}\text { Cust_loyal } \\
\text { Cust_sat } \\
\text { Cust_loyal } \longleftarrow \\
\text { switch_cost }\end{array}$ & $\begin{array}{l}.552 \\
.192\end{array}$ & $\begin{array}{l}.052 \\
.070\end{array}$ & $\begin{array}{l}8.589 \\
2.984\end{array}$ & $\begin{array}{l}.000 \\
.003\end{array}$ & supported \\
\hline
\end{tabular}




\begin{tabular}{|l|l|l|l|l|l|l|}
\hline H5 & $\begin{array}{l}\text { Swtitch_beh } \\
\text { Cust_sat }\end{array}$ & -.072 & .079 & -.889 & .375 & $\begin{array}{l}\text { Not } \\
\text { support }\end{array}$ \\
\hline H6 & $\begin{array}{l}\text { Switch_beh } \\
\text { switch_cost }\end{array}$ & -.201 & .108 & -2.473 & .014 & supported \\
\hline
\end{tabular}

\section{Figure: Structural model:}

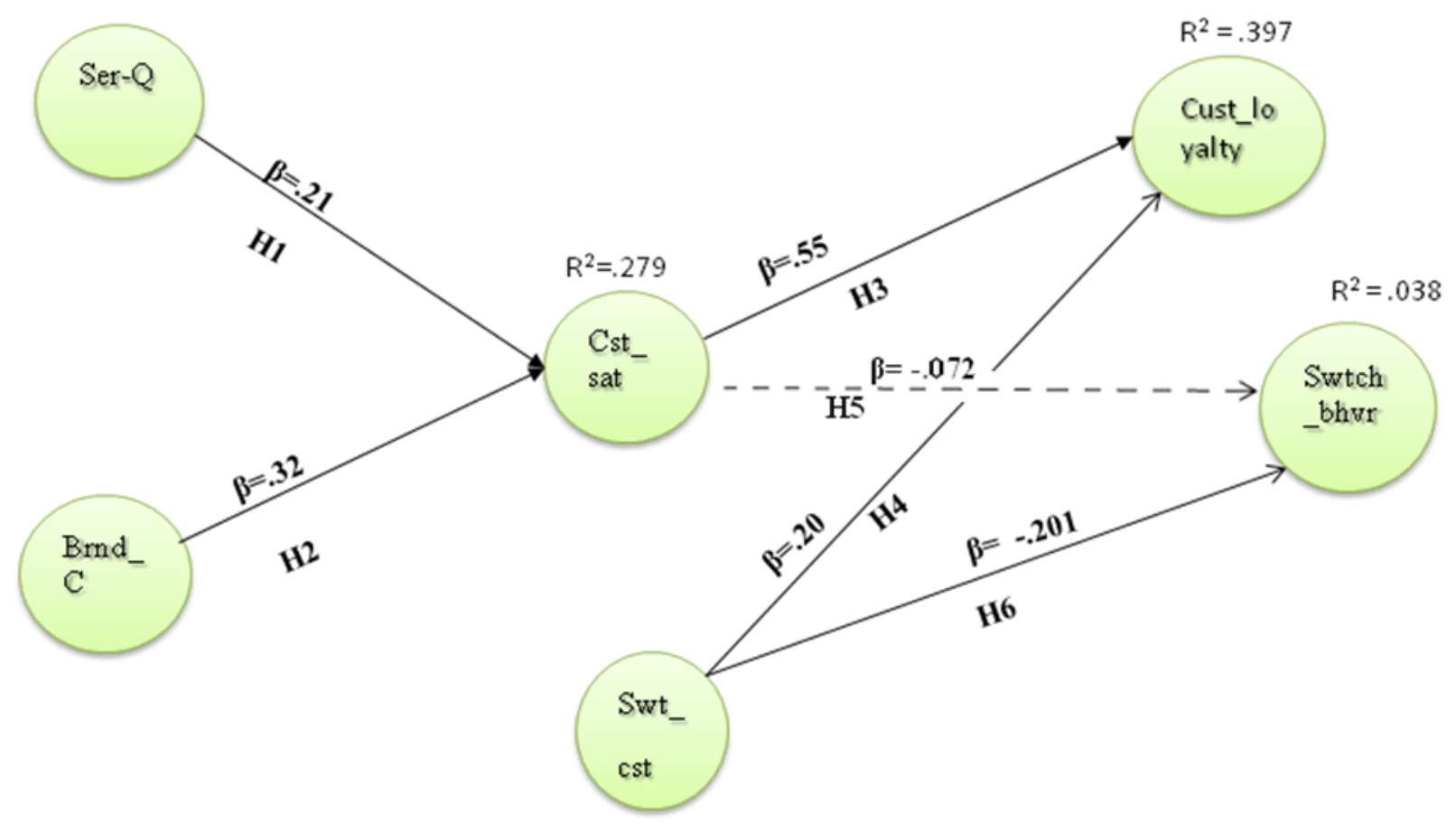

\section{Discussion:}

The main objective of this research has been to explore the acceptance of high technology cell phones in the context of a developing country in contrast to the enormous research that was conducted in developed countries. Pakistan has been an ideal country for that due to high penetration of new technology introducing by different cell phone companies, companies are trying keep loyal their customers but rapidly changing technology and intense competition making this task very tough.

Current study formulated acceptance of high technology cell phone brand model to include customer satisfaction as an antecedent of customer loyalty and decrease in customer satisfaction cause of customer switching behavior. The results obtained from the analysis allowed us to verify the established hypotheses and to understand the relationship between different variables of technology acceptance model. Now discretely we discuss these finding and their implications in the following section. 
In this study we explore that the customer loyalty and switching behavior can be measured by means of the following constructs: Service quality, brand commitment, customer satisfaction, switching cost. In addition to this, we presented exploratory analyses of consumer switching behavior exhibited by young and old respondents as well as lower and higher educated respondents. This research makes a considerable contribution for an improved understanding of the linkage among satisfaction of customer and customer loyalty.

As of the variables that were used to measure the customer satisfaction, service quality and brand commitment proved to have important relation in comparison with satisfaction. Firstly, the more satisfied individuals were with the brand of cell phone they used, the greater the possibility that they would remain with the same brand. This result appears to support the outcomes of a former study in approximately the same field. In a previous research Coulter et al. (2003) reported that when consumers are content with the brand they use they are less willing to switch for a different brand. Secondly, the more committed individuals are to their cell phone brand, there is less chance to switch for other brands.

The result confirms similar outcome reported in research studies performed in other fields on the topic of brand commitment (Coulter et al., 2003). LaBarbera and Mazursky (1983) supported the assumption that satisfaction has an important role in the switching behavior of consumers, except for brand commitment, and this is confirmed in the current study on cell phones. But in our research it is proved that there is insignificant relation between customer satisfaction and switching behavior.

Our study is about cellular phones and here it is demonstrated that dissatisfaction does not initiate switching behavior, it could happens due to any reason but most strong point is rapidly change in technology. Cellular companies are specially concentrating on R\&D to add features in their products to seek the attention of customers.In 2000, Ganesh et al. stated that market comprised of three groups of customer, satyer, dissatisfied switchers and satisfied switchers: stayers are the group of customers whom stay with brand and do not switch for others. Dissatsfied switchers are the group of individuals whom had switch from other supplier/companies due to their dissatisfactory feelings and finally satisfied switchers are those individuals whom had switched toward others not because of dissatisfactory feelings.

Result proved that relation of switching cost and loyalty is positive and significant, it means customer desire to change cell phone brand but there is a barrier of switching cost that create restriction to change .Gronhaug and Gilly(1991) explain that a customer who is dissatisfied may remain with their present provider if switching costs are too high. Fornell (1992) note that high switching costs can prevent customer switching.

These results verified strong relationship between customer satisfaction and customer loyalty. Oliva et al., 1992 explore this in research when satisfaction increase and reaches a certain level, loyalty increases significantly; at the same time, when satisfaction decline to a certain point, loyalty dropped equally dramatically. In our study, as the customer satisfaction measurement raises one unit from agree to strongly agree, the customer loyalty indices increase by over 100 percent. 
Results verified that customer satisfaction does not equal customer loyalty, satisfaction is antecedent of loyalty, first a customer should be satisfied then he become loyal with brand .Two measures of customer loyalty used in this study were the respondent's satisfaction and the switching cost to find out either customer is satisfied and loyal and recommending the cell phone brand that he is using to others or using the brand because of moving cost is very high .

Scales compares the scores on overall satisfaction with loyalty is high in case of standardized brands such as Apple user, we have just 5\% iPhone user but they are highly satisfied and loyal because of high quality and eventually high level of brand commitment. Mostly respondents are students, categorize in low income group, using Nokia ,Q mobile or Chinese cells tend to switch but switching cost for them is high so they have to use the particular brand because of switching high cost for other brands like apple and Samsung.

This research discloses that as switching cost decrease, possibilities of customer switching increase toward high technology cell phone brand. Customer of young age want to have a cell phone that has quite distinct position in market,61\% respondents are Nokia users, some of them show their loyalty for brand, because it is providing good quality in very reasonable price. Most costly brand that only 5\% respondents are using is Apple; user of other brands will bear high switching cost for this brand. Results of present research are consistent with several past researches that switching costs are the main cause of customer behavioral loyalty in cellar industry. So this is alignment of the result of this research with this past research in which Droge and Chiou indicate that just satisfaction is not sufficient to keep a customer loyal with brand. 7.Recommendations:

We are providing some strategic recommendations for cellular companies;

First, cell phone companies must, moreover all above, maximize customer satisfaction in order to boost customer loyalty. In particular, cellular companies should direct their attention on quality, to seek customer interest they have to offer best quality as compared to their competitors.

Second, cellular companies should focus on uniqueness and add some distinct features, through research and development, to retain customers in this highly unstable environment. It become unstable because of very rapid growth of technology.

Third, companies should formulate better advertisement strategies to increase awareness for new customers and make stronger brand commitment their present customers. Companies ought to offer discounts, offer gifts and vouchers for new customers; it has positive influence on customer satisfaction.

Fourth, the reason considerably prominence customer switching behavior, come into sight are switching costs such as move-in cost, loss cost, and time for searching better option. Cellular companies must continuously build up customer reward programs that concretely compensate customers, such as price discounts, in order to increase loss cost and move-in cost. 
In saturated markets it seems essential to build switching barriers to maintain market shares and growth. Thus, cellular companies have to increase the switching cost in favor of customer retention for their brand.

\section{Limitations and Future research:}

After concluding all results, the current study opens numerous areas to be investigating in the future researches. Future research can confine and enlighten the results for many other factors that are not take into account in our study due to shortage of time, small sample size. In this research two variables included, customer satisfaction and switching cost that proves to be influential on customer loyalty. But there are still many other factors are that influence customer loyalty.

The current study focus on customer satisfaction that leads to loyalty or may be switching behavior, which do not always become definite outcomes of customer behavior, therefore, future research may possibly obtain results from other factors like intentional or planned or habitual switching behavior that is major problem for cellular companies in this era and prices of cell phones. These variables can further help us to understand loyalty of customers and switching behavior of customers.

\section{References:}

[1]Alexandris ,K., Dimitriadis ,N. and Markata ,D.(2002), “Can perceptions of service quality predict Behavior intentions ? An exploratory study in the hotel sector in Greece ", Managing Service Quality, Vol. 12No. 4,pp. 224- 32.

[2]Aydin, S.andOzer, G.(2005),"An analysis of antecedents of customer loyalty in the Turkish Mobile communication market”, European Journal of Marketing, Vol.39Nos7/8,pp.910-23.

[3]Bitner, M.J.and Hubbert, A.R.(1994),"Encounter satisfaction versus overall satisfaction versus quality”, in Rust,R.T.and Oliver,R.L.(Eds), Service Quality: New Directions in Theory and Practice, Sage Publications, London.

[4]Brady, M.K.andCronin,J.J.(2001), “Some new thoughts on conceptualizing and measuring service quality: a hierarchical approach”, Journal of Marketing,Vol.65No.3,pp.34-49.

[5]Burnham, T. A., Frels, J. K., \& Mahajan, V. (2003). Consumer Switching Costs: A Typology, Antecedents, and Consequences. Journal of the Academy of Marketing Science, 31(2), 109-126. http://dx.doi.org/10.1177\%2F0092070302250897

[6]Chiou, J. S., \& Droge, C. (2006). Service Quality, Trust, Specifi Asset Investment, and Expertise: Direct and Indirect Effects in a Satisfaction-Loyalty Framework. Journal of the Academy of Marketing Science, 34(4), 613-627. http://dx.doi.org/10.1177\%2F0092070306286934

[7]Clemes, M. D., Gan, C. and Kao,T.H.(2007b),"University satisfaction :an empirical analysis”, Journal of Marketing for High Education,Vol.17No.2,pp.292-325.

[8] Colgate ,M. and Lang ,B.(2001),"Switching barriers in consumer markets :an 
investigation of the financial services industry", The Journal of Consumer Marketing,Vol.18Nos4/5, pp.332-48.

[9]Coulter, R. A., Feick, L., \& Price, L. L. (2003). Rethinking the Origins of Involvement and Brand Commitment: Insights from Postsocialist Central Europe. Journal of Consumer Research, 30(2), 151-169. http://dx.doi.org/10.1086\%2F376809

[10]Creswell, J.W. (1994) Research Design: Qualitative \& Quantitative Approaches. London: SAGE Publications

[11]Crosby, L.A. ,Evans ,K.R.,\& Cowles, D.(1990).Relationship quality in services selling: An interpersonal influence perspective. Journal of Marketing, 54(3),68-81

[12]Cui, G., \& Wang, Y. (2010). Consumers' SKU choices in an online supermarket: a latent class approach. Journal of Marketing Management, 26(5-6), 495-514. http://dx.doi.org/10.1080\%2F02672570903534704

[11]Dagger, T. S. ,Sweeney ,J .C.and Johnson, L.W.(2007),“A hierarchical model of service health quality”, Journal of Service Research,Vol.10No.12,pp.123-42.

[13]Deng, Z.,Lu, Y.,Wei ,K .K., \& Zhang, J.(2009).Understanding customer satisfaction And loyalty: An empirical study of mobile instant messages in China. International Journal of Information Management, doi :10.1016/ j.ijinfomgt.2009.10.001

[14]DeRuyter,K.,\& Wetzels , M.G.M.(2000).The impact of perceived listening behavior invoice-to-voice service encounters. Journal of Service Research, 2(3),

[15]Dick ,A.S.,\& Basu,K.(1994).Customer loyalty: Toward an integrated conceptual framework. Journal of the Academy of Marketing Science, 22(2),99-113.

[16]Fornell,C.(1992).A national customer satisfaction barometer :The Swedish experience. Journal of Marketing, 56(1),6-21.

[17]Ganesh J M ,Arnold J, Reynolds K E. Understanding the customer base of service providers: an examination of the differences between switchers and stayers. J Mark 2000 ; 64(3):65-87.

[18]Garland,R.(2002), "Estimating customer defection in personal retail banking”, International Journal of Bank Marketing,Vol.20 No.7,pp.317-24.

[19]Garland,R.(2002), "Estimating customer defection in personal retail banking”, The International Journal of Bank Marketing,Vol.20No.7,pp.317-25.

[20]Gerpott,T.J.,Rams,W., \& Schindler, A. (2001).Customer retention, loyalty and satisfaction in the German mobile cellular telecommunications market. Telecommunications Policy, 25(4),249-269.

[21]Gronhaug,K. and Gilly, M.C.(1991),“A transaction cost approach to customer dissatisfaction and complaint actions", Journal of Economic Psychology,Vol.12,pp.165-83.

[22] Gronroos,C.(2000), Service Management and Marketing,2nded.,Wiley, Chichester. 
[23]Jones M A, Mothers baugh D L,Beatty S E .Switching barriers and repurchase intentions in services. J Retailing2000;76(2):259-74.

[24]Jones,T.O. and Sasser, W.E .Jr (1995),“ Why satisfied customers defect”, Harvard Business Review,Vol.73No.6,pp.88-99.

[25]Kiesler, C.A., 1968. 'Commitment'. In: P.A. Abelson et al. (Eds.), Theories of Cognitive Consistency: A Source Book (pp. 448-455). Chicago, IL: Rand McNally.

[26]Kumar, A. (2005). Explaining consumer acceptance of handheld Internet devices. Journal of Business Research, 58(5), 553-568.

[27]LaBarbera, P. A., \& Mazursky, D. (1983). A Longitudinal Assessment of Consumer Satisfaction/Dissatisfaction: The Dynamic Aspect of the Cognitive Process. Journal of Marketing Research, 20(4), 393-404. http://dx.doi.org/10.2307\%2F3151443

[28]Lee,M.andCunningham,L.F.(2001),“Acost/benefitapproachtounderstandingserviceloyalty ”,TheJournalofServicesMarketing,Vol.15No.2,pp.113-30.

[29]Matthews,C.and Murray,D.(2007), "Helping bank customers switch :a case study", Journal of Financial Services Marketing,Vol.11No.4,pp.360-70

[30]Mavri, M. and Ioannou ,G.(2008), “Customer switching behavior in the Greek banking services using survival analysis”, Managerial Finance, Vol.34No.3,pp.186-97.

[31]Morgan,R.M.and Hunt,S.D.(1994), “The commitment- trust theory of relationship marketing”,Journal of Marketing,Vol.58,July,pp.20-38.

[32]Moss, S., Prosser, H., Costello, H. (1998). Reliability and validity of the PAS-ADD Checklist for detecting psychiatric disorders in adults with intellectual disability. Journal of Intellectual Disability Research. 42, 173-183.

[33]Nunnally, JC. (1970). Introduction to Psychological Measurement. New York: McGraw-Hill.

[34]Oliva TR,OliverL,MacMillanI.A catastrophe model for developing service satisfaction strategies.JMark1992;56(3):83-95.

[35]Oliver,R.L.(1997). Satisfaction: A behavioral perspective on the consumer. Boston: Irwin McGraw-Hill.

[36]Parasuraman , A., Zeithaml, V.A., \& Berry, L.L.(1985).A conceptual model of service quality and its implications for further research. Journal of Marketing, 49(3),41-50.

[37]Parasuraman,A.,Zeithaml,V.A.,\&Berry,L.L.(1988).SERVQUAL:Amultiple-item scale for measuring consumer perceptions of service quality. Journal of Retailing, 64(1),12-40.

[38]Reichheld ,F.F.(1996). Theloyaltyeffect.Boston:HarvardBusinessSchoolPress.

[39]Raju, S., Unnava, R. H., \& Votolato Montgomery, N. (2009). The Effect of Brand 


\section{Macrothink}

Commitment on the Evaluation of Nonpreferred Brands: A Disconfirmation Process. Journal of Consumer Research, 35(5), 851-863. http://dx.doi.org/10.1086\%2F592816

[40]Soderlund,M.(1998).Customer satisfaction and its consequences on customer behavior revisited. International Journal of Services Industries Management, 9(2),169-188.

[41]Thompson, D. V., Hamilton, R. W., \& Petrova, P. K. (2009). When Mental Simulation Hinders Behavior: The Effects of Process-Oriented Thinking on Decision Difficulty and Performance.Journal of Consumer Research, 36(4), 562-574. http://dx.doi.org/10.1086\%2F599325

[42]Zeithaml,V.A.,Berry,L. and Parasuraman, A.(1996),"The behavioural consequences of service quality”, Journal of Marketing, Vol.60 No. 2,pp.31-46.

[43]Zeithaml,V.A.,\& Bitner,M.J.(2000). Services marketing: Integrating customer focus Across the firm. Madison: McGraw-Hill.

[44] Zikmund, W.R. (1997). Business Research Methods (5th Ed.), Texas: The Dryden Press. 